\title{
砕波に伴う潜堤周辺の波・水粒子速度場の 細部構造に関する実験的研究
}

\author{
岩田好一朗*・川崎浩司 ${ }^{* *}$ ・亀崎大 輔 ${ }^{* * *}$
}

\section{1. 序}

\section{論}

潜堤は，波浪制御のみならず海域の景観を損なわない など優れた機能をもつ海岸構造物であるが, 最近潜堤を 藻場の造成場所として，また魚介類などの集魚機能など 合わせて具備さすことが強調されるにつれて, 砕波に伴 う潜堤周辺の流速場の細部構造を明らかにすることが重 要になってきた。 3 次元波動場について, 潜堤による砕 波後の波形や流速場の特性は明らかにされつつあるが (例えば，信岡ら，1993；青野ら，1995）, 流速場の内部 構造に関しては不明な点が多く, 研究の余地を多く残し ている.

本研究では, 詳細な水理実験を行い, 3 次元波動場に 設置された潜堤による砕波の 3 次元特性抢よび确波後の 潜堤周辺に扔ける波の挙動特性と水粒子流速場の細部構 造を，入射波および潜堤の幾何スケール比と関連づけて 考究することを目的とする.

\section{2. 水理実験と解析方法}

名古屋大学の平面波浪水槽(長さ $28 \mathrm{~m}$, 幅 $11 \mathrm{~m}$, 深さ $0.8 \mathrm{~m})$ を用いて, 水槽内の水平床上に不透過矩形型潜堤 を設置し, 砕波限界, 砕波形式, 砕波位置(実験 I), 砕 波後の波形の変化 (実験II) および流速場の内部特性 (実 験III）の 3 種類の水理実験を行った。実験では, 潜堤の 堤幅 $B$ と堤高 $D$ をとれぞれ $B / L_{i}=0.3, D / h=0.6\left(L_{i}\right.$ : 入 射波長, $h$ : 静水深) と固定し, 潜堤の堤長 $W$ のみを 5 種 類 $\left(W / L_{i}=0.5,1.0,1.5,2.0,2.5\right)$ 変化させ, 静水深を 40 $\mathrm{cm}$ と一定に保った。作用波は, すべて潜堤前面に対し直 角入射する規則波であり，周期 $T$ を $0.8,1.2,1.68 \mathrm{~s}$ の 3 種類とした。なお, 実験II とIIIでは, 入射波高 $H_{i}$ を非線 形パラメターП（合田，1983）が $0.08 ， 0.09$ となる 2 種 類を採用した. 水位変動の計測を, 波進行方向に対し潜 堤前面から約 2.0 波長, 潜堤の中心線から波進行直角方 向に対し約 1.5 波長の領域内で， 0.1 波長間隔で設けた 合計約 300 地点で電気容量式水位計を用いて詳細に行っ

\footnotetext{
*フェロー 工博 名古屋大学教授 土木工学教室

** 学生会員 工修 名古屋大学大学院 工学研究科土木工学専攻

*** 工修 東亜建設工業 大阪支店土木部設計積算課
}

た.同時に, 砕波状況を $8 \mathrm{~mm}$ ビデオカメラを用いて撮影 した。また，流速の時間変化を，水位変動の計測範囲と ほほ同範囲に扔いて約 120 地点, 水深方向に対し静水面 から $0.3 h$ 間隔で設けた 3 地点, 合計約 360 地点で電磁 流速計を用いて詳細に計測した。

計測された水位と流速の時間変動を $0.04 \mathrm{~s}$ で離散化 し，ゼロ点とデー夕間の位相のずれを補正して解析を 行った。解析対象とする波は，造波板や消波装置などか らの反射波の影響がなく波形が定常状態に達している 3 波である. その 3 波に対し, 波高 $H$, 平均水位 $\bar{\eta}, x$ と $y$ 方向の定常流 $\bar{u}, \bar{v}$, 渦度 $\omega_{z}$ を式 (1) 上り求めるととも に, FFT法を用いてスペクトル解析を行った。また, 撮 影した映像を 30 コマ/秒ごとにモニターに写し出し, 砕 波限界, 砕波位置, 砕波形式, 砕波持続領域などを読み とった.

$$
\bar{Q}=\frac{1}{3 T_{i}} \int_{\tau}^{\tau+3 T_{i}} Q d t, \quad \omega_{z}=\frac{\partial v}{\partial x}-\frac{\partial u}{\partial y}
$$

ここで, $Q$ は水位変動 $\eta$ および $x$ と $y$ 方向の流速 $u, v$ を 表し, $\tau$ は 3 波目の最初の時間である.

次元解析によれば，本実験条件において，潜堤による 砕波特性と砕波後の波挙動およびその内部特性は，相対 波高 $H_{i} / R$, 水深波長比 $h / L_{i}$, 無次元堤長 $W / L_{i}$ の 3 つの 量に大きく支配されるので，これらの効果についても考 察する.

\section{3. 砕波特性}

\section{1 砕波限界と砕波形式}

図一 1 は, 潜堤による砕波限界扔よび确波形式と $H_{i} / R$ $\left(R\right.$ : 天端水深) および $W / L_{i}$ の関係を示し，（a）と（b) はそれぞれ $h / L_{i}=0.2,0.4$ の場合である。また， $W / L_{i}=\infty$ は, 岩田ら (1996) が行った 2 次元の実験結果 である(以下，同様とする)。なお，本研究では，波面が 不連続となった時を研波と定義した。図一1 から, 本実験 の範囲では砕波限界 (図中の B.L.) に対する $W / L_{i}$ の影響 はあまり確認できないが, 2 次元の場合 $\left(W / L_{i}=\infty\right)$ と 比較すると， 3 次元の方が小さくなっている. 3 次元波 動場の場合, 潜堤両端部で, 水深急変部での波の屈折や 潜堤による散乱波の影響から，局所的に波高が増大する 


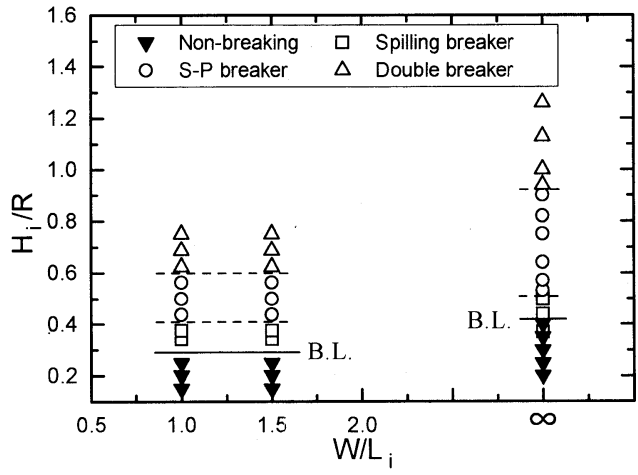

(a) $h / L_{i}=0.2$

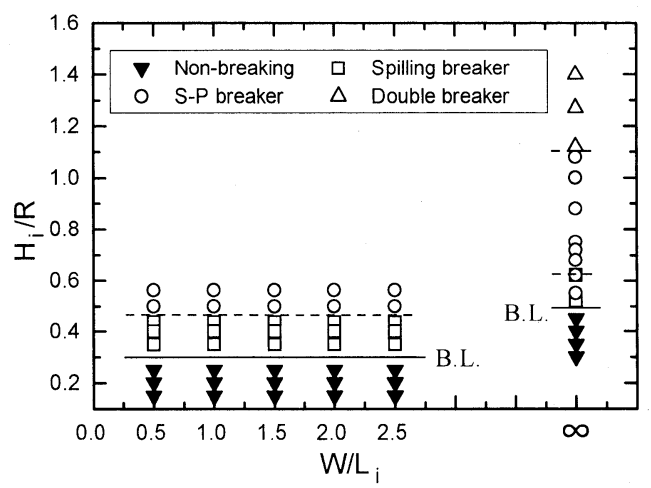

(b) $h / L_{i}=0.4$

図一1 破波限界と破波形式

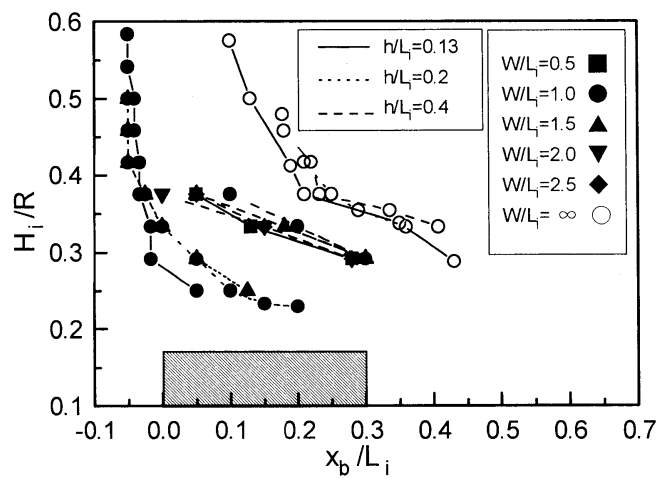

図一 2 波破位置

ことをビデオ解析から観察しており，そのため 3 次元の 方が砕波しやすいと考えられる。

つぎに, 砕波形式であるが, 本研究では, Spilling 型砕 波(図中の $\square$ 印), Spilling 型砕波と Plunging 型砕波の中 間の性質をもつ S-P 型䂶波(図中の○印)，片野ら (1992) が観察した, 引き波時に生じる戻り流れの効果から潜堤 前面でさらに潜堤上で砕波する二段砕波 (Double breaker，図中の $\Delta$ 印）の 3 種類に分類され， $H_{i} / R$ が大
きくなるにつれて Spilling 型砕波, S-P 型砕波, 二段砕波 へと変化していくことが判明した。なお，図中の印は 非砕波を表す。また，2次元の場合（岩田ら，1996）と 同様，3 次元の場合も， $H_{i} / R$ 法砕波限界と砕波形式を支 配する重要なパラメターのひとつであることが確認でき る。そして，砕波形式は，砕波限界と同様，本実験の範 囲では $W / L_{i}$ が変わってもあまり変化しないが， 2 次元 の場合と比較すると， 3 次元の方が砕波規模が大きい. $h / L_{i}$ による違いについてみると, 砕波限界抢よび各砕波 形式へ移行するときの $H_{i} / R$ の值は, $h / L_{i}=0.2$ より, $h / L_{i}=0.4$ の方がわずかに大きく, $h / L_{i}$ が大きくなると, 進行波は深海性を帯び潜堤による影響の度合いが若干小 さくなるためと考元れる。

\section{2 砕波位置}

ビデオの写真解析から，砕波限界より少し大きい入射 波高の場合，進行波は潜堤端部付近でのみ局所的に砕波 するが，入射波高がさらに大きくなると，研波する範囲 が潜堤中央まで広がり，特に大規模の砕波の場合，潜堤 端部から中央にかけてほほ同時に䂶波することが認めら れた。図一2 は，W/L をパラメターとする無次元砕波位 置 $x_{b} / L_{i}$ と相対波高 $H_{i} / R$ の関係を図示したものである. ここで， $x_{b}$ は潜堤沖側端部から砕波点までの距離，図中 の実線，点線，破線はそれぞれ $/ L_{i}=0.13,0.2,0.4$ であ る. 同図より, 本実験の範囲では砕波位置に対する $W / L_{i}$ の影響はあまり認められない. $H_{i} / R$ の増大に伴い, 砤波 位置は沖側方向へ移動し, $H_{i} / R \geq 0.5$ になると, 入射波と 潜堤加ら反射波の干渉による部分重複波の影響から， $x_{b} / L_{i}=-0.05$ とほぼ一定になり潜堤前面で砕波する。 また, 3 次元の場合, 2 次元と比べて $x_{b} / L_{i}$ は沖側に移動 して抢り，前述したように潜堤端部付近で局所的に波高 が増大し，砕波しやすくなるためと推察される。水深波 長比別にみると, $h / L_{i}$ が大きくなると，進行波は深海性 を帯び潜堤との干涉が弱くなるため, 砕波位置は潜堤岸 側に移動する。

\section{4. 破波後の波の挙動特性}

\section{1 波高と平均水位}

図一 3 に一例として示すように，砕波に伴う潜堤周辺 の波高は，水深急変部で波と潜堤の非線形干渉が強まる ため，潜堤上で入射波高より大きく，特に潜堤端部付近 で局所的な波の屈折や潜堤による散乱波の影響から，よ り大きくなる，また，潜堤岸側背後で波高の低減，潜堤 周辺で回折波が明瞭にみられる。

図一4 は，潜堤の中心線 $\left(y / L_{i}=0\right)$ での波高 $H$ と平均 水位 $\bar{\eta}$ を同時に示したものである。潜堤前面では入射波 と潜堤からの反射波の相互干渉から約 $L_{i} / 4$ 間隔ごとに 腹と節が交互に現れる部分重複波の形成が認められる. 


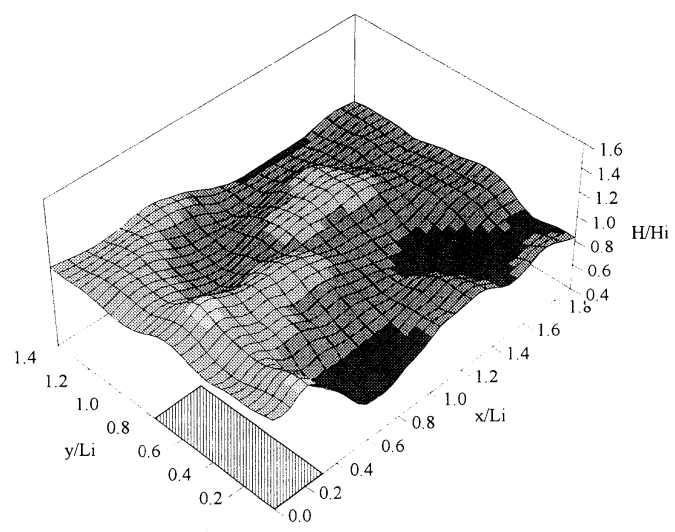

図-3 波高分布（ $\Pi=0.08, W / L_{i}=1.5 ）$

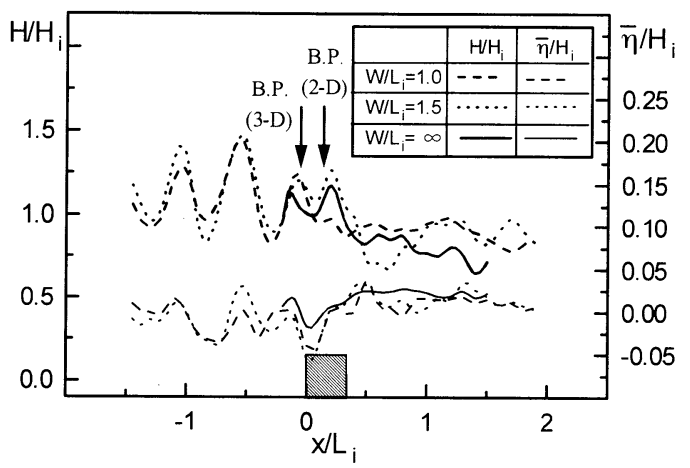

図-4 波高と平均水位の空間分布 $\left(y / L_{i}=0 ; h / L_{i}=0.2, \Pi=0.08\right)$

潜堤上と潜堤岸側背後では，2次元の方が波高の低減が 大きいことがわかる.これは，3次元の場合，潜堤両端 部付近で波高が急激に増大し最初に砕波するため, 後述 するように，潜堤端部付近を中心とした円筒状に広がる 高周波成分の自由波が新たに発生している可能性があ り，これと砕波後再び波として形成される再生波が干渉 し合い，2次元と比べて波高の低減が小さくなったと推 測される.つぎに, 平均水位は, 砕波点（図中の B.P.) 付近まで静水面より低下し, 砕波点以降上昇し静水面よ り高い水位になることがわかる。 また， 2 次元と 3 次元 を比較すると, 3 次元では, 砕波後波エネルギーが多方 向に分散されるため平均水位の上昇は 2 次元に比べてや や小さい.

\section{2 スペクトル解析結果}

図一5 は, 無次元波高スペクトル $2 A(f) / H_{i}(A(f)$ : 振 幅スペクトル, $f:$ 周波数) の鳥瞰図であり, (a) と（b) はそれぞれ基本，2 倍周波数成分の場合を表す。潜堤背 後領域において, 基本周波数成分が減少している領域と 波と潜堤の非線形干渉の影響から 2 倍周波数成分が増加

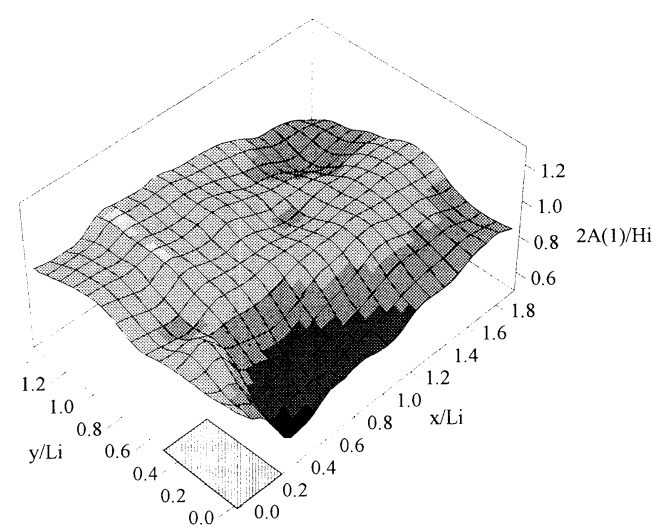

（a）基本周波数

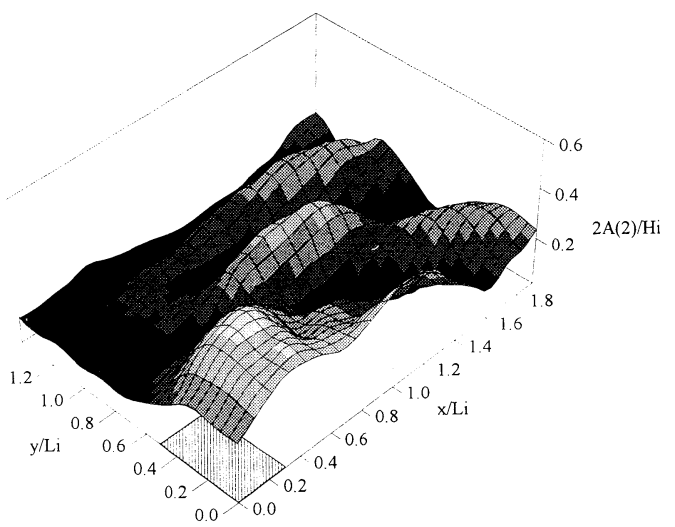

(b) 2 倍周波数

図-5 潜堤周辺の無次元波高スペクトル $\left(h / L_{i}=0.2, W / L_{i}=1.0, \Pi=0.08\right)$

している領域は概ね一致しており, 基本周波数成分の波 エネルギーが高周波数成分へ移行していることがわか る. しかし, 再生波形成後 $\left(x / L_{i} \geq\right.$ 約 1.6), 再び基本周 波数成分は増大し，2 倍周波数成分は変動しながら減衰 する. 潜堤背後領域以外では，2 倍周波数成分は潜堤岸 側端部を中心として周期的に変動している. 2 次元波動 場で非砕波の計算を行った Massel (1983) によると, 波 と潜堤の非線形干渉から高次の周波数成分の自由波が発 生し, 2 倍周波数成分は潜堤背後で周期性をもって変動 すると述べている，本実験は砕波の場合であるが，上述 した傾向とほぼ同様な傾向を示し，2 倍周波数成分の自 由波が発生している可能性があると考えられる，また， 3 倍周波数成分についても，2 倍周波数成分と同様な傾 向が認められたがその值は小さかった。紙面の制約上図 示できないが, $h / L_{i}=0.13$ の場合, $h / L_{i}=0.2,0.4$ と比べ て, 進行波は浅海性を帯びるため波と潜堤の干渉が強く, 基本周波数成分は顕著に回折波がみられた。 2 倍周波数 成分については，図--5(b)に示すようなビートを打つ波 


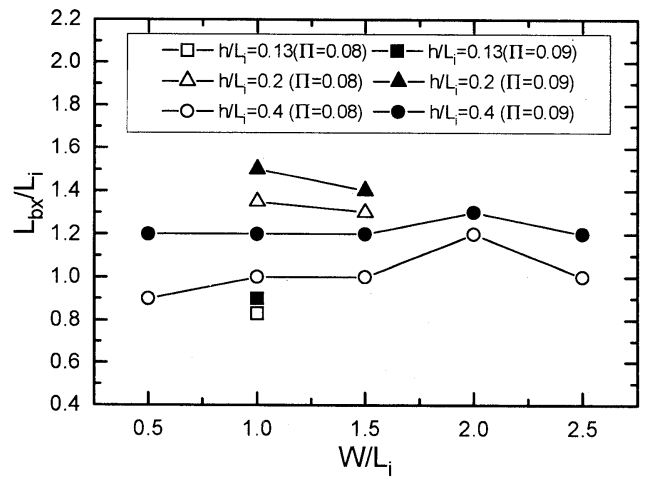

（a） $x$ 方向の最大破波持続距離

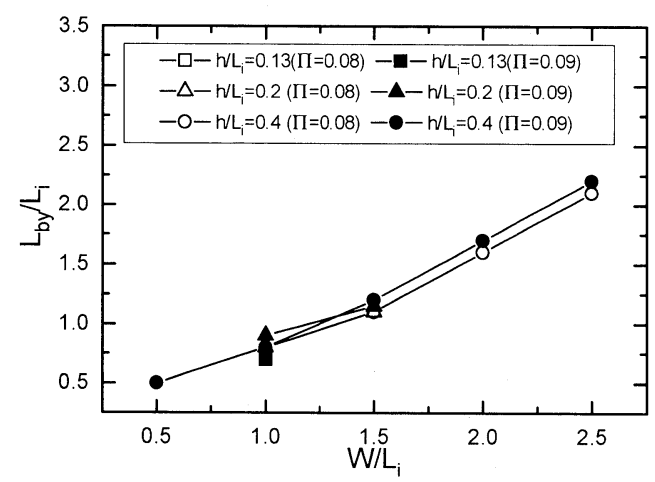

(b) $y$ 方向の最大破破持続距離

図一6 最大破波持続距離と堤長の関係

形が確認できなかった。

\section{3 破波持続領域}

図一6(a) と（b）は，それぞれ $x, y$ 方向の無次元最大 砕波持続距離 $l_{b x} / L_{i}, l_{b y} / L_{i}$ と $W / L_{i}$ の関係を示したもの である。図一6より，W/L り変動していないものの, $l_{b y} / L_{i}$ は潜堤背後領域が広が るため増加し, その増加率はほぼ一定である.また， Пの 值が大きくなると, $l_{b x} / L_{i}$ は増大するが $l_{b y} / L_{i}$ はあまり 変化がない. このことは, 入射波高の増加に伴い $x$ 方向 にのみ砕波の影響が持続することを意味している。そし て, $h / L_{i}$ の違いによる $l_{b y} / L_{i}$ の影響はあまり認められ ず, $l_{b x} / L_{i}$ の場合 $h / L_{i}=0.2$ のとき最も大きくなってい る.これは,この場合の砕波形式は S-P 型砕波で最も砕 波規模が大きかったためである. なお, ビデオの写真解 析によると, $l_{b x} / L_{i}$ の生じる地点は, $W / L_{i}$ が大きくなる につれて潜堤の中心線から潜堤端部の方にずれることが 認められた。

\section{5. 潜堤周辺の流速場}

図一7(a)，(b) は，それぞれ $z / h=-0.3,-0.9$ での潜堤 周辺における定常流を示したものである, なお, 定常流

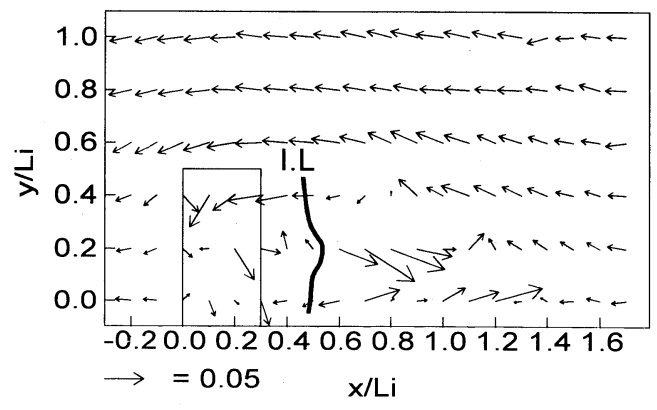

(a) $z / h=-0.3$

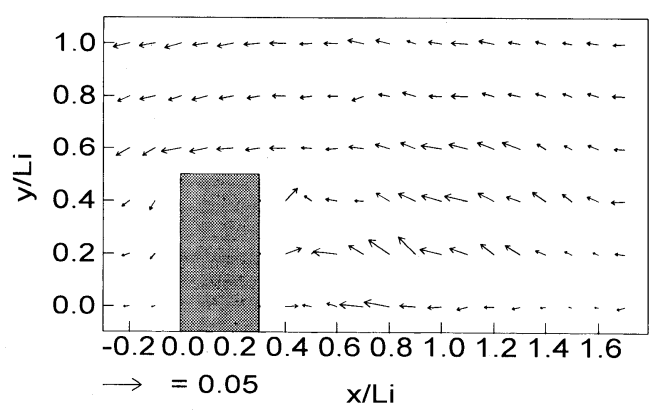

(b) $z / h=-0.9$

图一7 潜堤周辺に抒ける定常流 $\left(h / L_{i}=0.2, \Pi=0.08, W / L_{i}=1.0\right)$

の流速は $\sqrt{g h}$ ( $g$ : 重力加速度, $h$ : 静水深) によって無 次元化している. 図一7(a)から, 潜堤の側方端部付近で は, 潜堤の中央部に比べて定常流の流速が大きく, 潜堤 中央に向かう定常流が発生しており, この流れは水深急 変部での波の屈折や波と潜堤の干渉によって生じた散乱 波の影響によるものと推察される.また，波頂部から飛 び出した水粒子が, 進行波前面に衝突する突込み線（図 中の I.L.) 以降で, 強い岸向き流れが発生している. 潜堤 から離れた側方では, 沖向き流れが卓越しており，この 流れは砕波による岸向きへの質量輸送を補う補償流と考 えられる. 信岡ら（1993）は, 小型平面水槽に矩形潜堤 を設置し，水表面にフロートを浮かべることにより自由 表面付近で循環流が発生することを観察している．信岡 らの観察結果と本実験で得られた定常流特性をまとめる と, 3 次元波動場の場合潜堤周辺の自由表面付近で平面 2 次元的な循環流が生じていると判断できる. 次に, 図 一7(b)より, 底層付近において $y / L_{i}=0.0 \sim 0.2$ の範囲で みられる戻り流れは, 潜堤側方を通して沖側方向に出て いない. 2 次元波動場に設置された潜堤周辺の流速を計 測した岩田ら（1996）によると, 潜堤背後において, 自 由表面付近では強い岸向き流れ, 中層および底層付近で は沖向き流れとなる鉛直 2 次元的な循環流が発生すると 報告しており，本実験においても， $x / L_{i}=0.4 \sim 1.2$, $y / L_{i}=0.0 \sim 0.2$ の範囲で鉛直 2 次元的な循環流が発生 


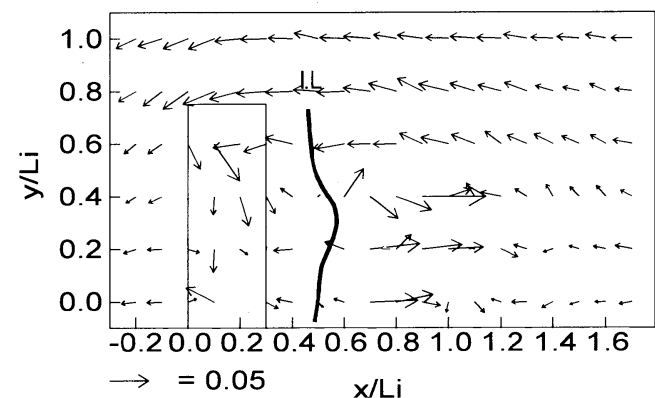

図一8 潜堤周辺における定常流 $\left(h / L_{i}=0.2, \Pi=0.08, W / L_{i}=1.5, z / h=-0.3\right)$

していると考えても間違いなさそうである，図一 8 は， 図一7 (a) と比べて, $W / L_{i}=1.5$ と異なる場合の定常流場 を示したものであり, $x / L_{i}=0.7 \sim 1.2, y / L_{i}=0.0 \sim 0.4$ の 領域に扔いて岸向き流れが卓越している.また，W/L 1.0 の場合の定常流特性と同様, 潜堤周辺で平面 2 次元 的な循環流が形成されている. 信岡ら（1993）の観察結 果をみると, $W / L_{i}=0.6$ の場合で, 強い岸向き流れは潜 堤中央で認められるが，本実験結果（図一7(a) と図一8) では, 潜堤端部から中央に約 $0.35 L_{i}$ の位置で生じてい る.したがって, 循環流の岸向き流れの卓越する位置は $W / L_{i}$ に支配されると考元られ, $W / L_{i} \leq 0.7$ の場合潜堤 中央で生じると予想される. 次に, 図一9 は, 図一7 と同 条件下で, 潜堤周辺の定常流の渦度を示したものである. なお，定常流の渦度 $\overline{\overline{\omega_{z}}}$ は，定常流に対し式（1）を使っ て求めた，図一9(a)をみると，潜堤岸側端部付近で隅角 部による影響から比較的規模が大きい渦が認められる。 図一9（a）と（b）から, 砕波形式が S-P 型砕波であるこ のケースでは, 突込み線の背後において, 図中の網掛け 部で示す $x / L_{i}=0.9 \sim 1.4, y / L_{i}=0.0 \sim 0.4$ の領域（図一9 (a)) と $x / L_{i}=0.5 \sim 1.0, y / L_{i}=0.0 \sim 0.3$ での領域 (図一9 (b) ) で的が大きく, 大規模渦が顕著に認められ, さら に $z / h=-0.3$ と -0.6 でその発生領域が異なっている ため 3 次元性を帯びていることがわかる.

\section{6. 結 論}

本研究で得られた主要な結論を以下に要約する.

1） 3 次元波動場の場合, 潜堤による砕波限界と砕波 位置は, $0.5 \leq W / L_{i} \leq 1.5$ の範囲で, $H_{i} / R$ と $h / L_{i}$ でほほ支配され, 砕波形式は, $H_{i} / R$ の増加に伴い, Spilling 型砕波, S-P 型砕波, 二段砕波へと移行す る.

2）波と潜堤の非線形干渉により，潜堤両端部を中心 として円筒状に進行する高次の自由波が発生する と考えられる。

3）砕波に伴い潜堤周辺で，潜堤岸側中央部で岸向き

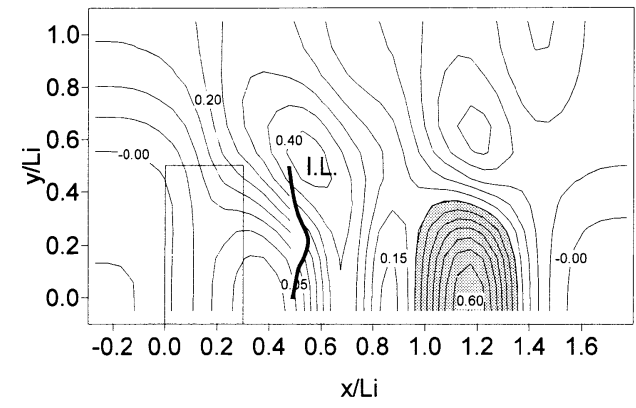

(a) $z / h=-0.3$

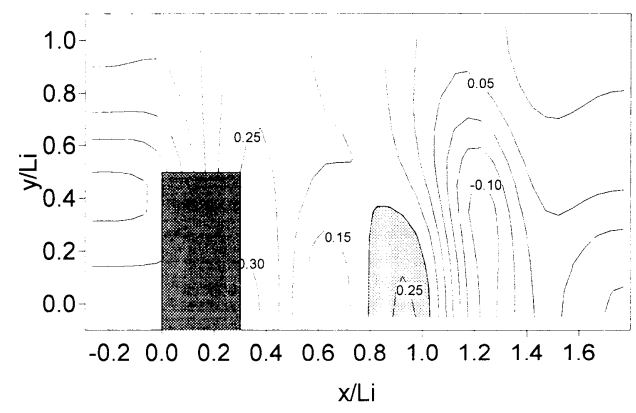

(b) $z / h=-0.6$

图一9潜堤周辺における定常過度 $\left(h / L_{i}=0.2, \Pi=0.08, W / L_{i}=1.0\right)$

流れ, 潜堤側方部で沖向き流れとなる平面 2 次元 的な循環流と自由表面付近では強い岸向き流れ， 中層および底層付近では沖向き流れとなる鉛直 2 次元的な循環流が発生する.

4）最も強い岸向き流れは, 潜堤端部から中心方向に 向かって約 0.35 波長付近で生じると判断される.

最後に, 本研究を行うにあたり水理実験等に協力して 頂いた名古屋大学大学院博士課程前期課程 1 年の新美達 也君と安藤敏宏君に謝意を表する。

\section{参 考 文 献}

青野利夫 • Eric. C. Cruz • 大中 晋・後藤智明（1995）：人工リー フ上の波と流れの現地観測, 海岸工学論文集, 第 42 巻, pp. 761-765.

岩田好一朗・川崎浩司・安藤敏宏（1996）：潜堤に上る砕波特性 とその内部機構に及活す波と潜堤の幾何スケール比, 海洋開 発論文集, Vol. 12 (印刷中).

合田良実 (1983)：波浪の非線形性とその記述パラメーター，第 30 回海岸工学講演会論文集, pp. 39-43.

信岡尚道・村上啓介・入江 功・松永厚彦・木原康成・牛房幸光 (1993): 潜堤構造物の海浜流制御と海岸保全機能, 海岸工学 論文集, 第 40 巻, pp. 261-265.

Massel, S. R. (1983): Harmonic Generation by Waves Propagating over a Submerged Step, Coastal Eng. Vol. 7, pp. 357-380. 